\title{
グルカゴンの腎機能に及ぼす効果一健常人と慢 性糸球体腎炎患者の比較一
}

\author{
徳本明秀* 上栘 次郎* 中岡 明 久* \\ 川崎寛 中* 平山干 里*
}

腎機能評価法として, 最近, 経口蛋白負荷法, Dopamine 法などが行われているが，今回腎血管 搪張作用をむつ Glucagon ${ }^{11}$ を, 健常成人および慢 性糸球体腎炎患者に投与し, 珡血行動態と尿中電 解質排泄能に及ぼす効果を比較検討した.

方法：健常成人 6 名（平均年齢 36 歳）(NL) 之慢性糸球体腎炎患者 11 名（平均年龄 32 歳） (CGN)を対象とした。なお血清クレアチニン值が $2 \mathrm{mg} / \mathrm{dl}$ 以上の患者は除外した，検査当日絶食に て, 午前 9 時に水 $500 \mathrm{ml}$ 飲水し, 10 時より 12 時まで, チオ硫酸ソーダ (Thios) とパラアミノ馬 尿酸 $(\mathrm{PAH})$ を点滴投与した. 10 時より 11 時ま でをコントロール期，11 時より 12 時までをテス ト期とし，乙の間 Glucagon (Glucagon Novo, 小 玉) (G) $10 \sim 15 \mathrm{ng} / \mathrm{kg} / \mathrm{min}$ で点滴投与した. $\mathrm{G}$ 投与前後で蓄尿, 尿測し, 尿中電解質を測定し た. また 10 時 30 分と 11 時 30 分に採血し， 血中電解質を測定した。尿中および血中 Thios, $\mathrm{PAH}$ 值よりそれぞれ糸球体濾過值 (GFR), 有効 腎血漿流量 (ERPF) を計算した.

結果: Ht はG負荷前後で NL, CGN 雨群とむ に不変であったが, albumin は軽度減少，血糖は 有意に上昇した。血清クレアチニン, $\mathrm{Na}$ は両群 と屯不変であったが, BUN, $\mathrm{K}, \mathrm{Cl}$ は CGN におい て，わずかではあるが有意に低下した. GFR は， NL ではコントロール值 $121 \pm 5$ (平均 $\pm \mathrm{SE}$ ) から $\mathrm{G}$ 負荷後 $155 \pm 6 \mathrm{ml} / \mathrm{min}$ 之增加 $(\mathrm{P}<0.001)$ し, また CGN でも $93 \pm 9$ から $127 \pm 13 \mathrm{ml} / \mathrm{min}$ と増

* 鳥取大学医学部第二内科 厂683 米子市西町 36-1

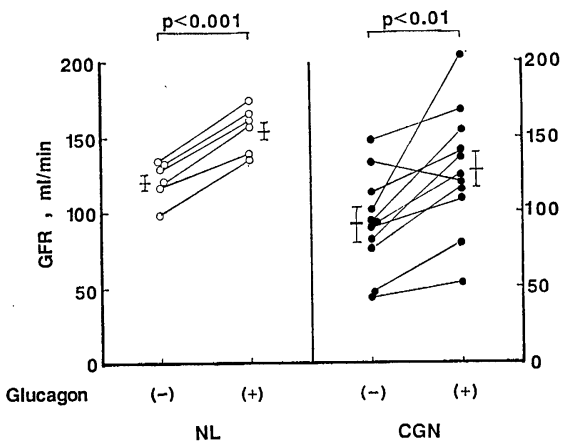

Fig. グルカゴンの GFR に対する，健康成人(NL) 之慢性系球体腎炎患者之の比較。

加 $(\mathrm{P}<0.01)$ した (Fig. ).

ERPF は, NL では G 負荷前 $625 \pm 66$ で, 負荷 後 $613 \pm 55 \mathrm{ml} / \mathrm{min}$ と無変化であったのに対し, GCN では $543 \pm 57$ から $755 \pm 76 \mathrm{ml} / \mathrm{min}$ と增加 $(\mathrm{P}<0.05)$ した.

Filtration fraction (GFR/ERPF) は, NL では $0.21 \pm 0.03$ 加ら $0.26 \pm 0.02$ と上昇 $(\mathrm{P}<0.05)$ し たが, CGN では $0.17 \pm 0.01$ から $0.18 \pm 0.01$ と有意な変化はなかった。

尿量は両群とも G 負荷前後で有意の差はみられ なかった. G 負荷後, 尿中 $\mathrm{Na}, \mathrm{Cl}$ は CGN にお いて有意に増加したが，NL では不変であった。 尿中 K 排泄は NL, CGN 両群ともにG負荷による 影響は観察されなかった。

次に，尿中電解質排泄と GFR との関係をみる ために, $\triangle \mathrm{GFR}$ (GFR 後值-GFR 前値) と $\Delta \mathrm{U}_{\mathrm{Na}} \mathrm{V}$ $\left(\mathrm{U}_{\mathrm{Na}} \mathrm{V}\right.$ 後值 $-\mathrm{U}_{\mathrm{Na}} \mathrm{V}$ 前值) との相関関係を調 
84 一般演題

べてみたＮNLでは，相関関係はなかったが， CGN では，両者間に有意の正の相関がみられ た.このような傾向は, $\Delta \mathrm{U}_{\mathrm{K}} \mathrm{V}, \Delta \mathrm{U} \mathrm{ClV}$ との間に むみられた.さらに $\triangle \mathrm{ERPF}$ (ERPF 後值-ERPF 前值）は， CGN においてのみ， $\Delta \mathrm{U}_{\mathrm{Na}} \mathrm{V}, \Delta \mathrm{U}_{\mathrm{K}} \mathrm{V}$, $\triangle \mathrm{U} \mathrm{ClV}$ と有意の正の相関があった.

考察：膵藏の $\alpha$-細胞より分泌されるグルカゴ ンは，たんに血糖調節作用のみならず，種々の臓 器, たとえば督蔵に対してその血行動態, 尿細管 機能などを調節しているてとが知られている。 そ のようなグルカゴンの作用を用いて，腎機能を評 価する試みが行われている. Parving らは正常人 に低濃度のグルカゴンを投与し, 系球体滤過值 (GFR) と有効腎血漿流量 (ERPF) の変化を調べた ところ, GFR は增加したが, ERPF は不変であっ たと報告している は，GFR および ERPF ともに增加した². この ような成績は，正常人と糖尿病患者では腎血行動 態の behavior が異なるととを示唆している.

今回，われわれは Parving らと同程度の濃度 のグルカゴンを正常人と慢性糸球体腎炎患者に投 与し，腎血行動態および尿中電解質排泄に対する 影響を検討した．GFR はグルカゴンによって両 群とむに增加したが, FRPF は前者で不変であっ たのに対し，後者では増加した. すなわち, filtration fraction (GFR/ERPF) は正常人では上昇した のに対し，腎炎患者ではほとんぞ無変化であっ た.これは, Parving らの糖尿病患者のデータと かなり一致しており，興味深い所見である。では なぜ，そのような反応の差が生ずるのか. 一つの 可能性として, 腎輸出細動脈に対するアンギオテ ンシンIIの作用が考えられる.すなわち，グルカ ゴンは輸入細動脈を拡張させる一方で1)，レニン 分泌を刺激し4)，アンギオテンシン II の産生を艺 進させ，輸出細動脈を収縮させる，その結果， GFR は增加するが, ERPF はあまり增加しない. したがって filtration fraction は上昇する. 一方,
腎炎患者では輸出細動脈の機能的, 器質的変化に より, アンギオテンシン II の効果が十分発揮され ないで, ERPF が増加するのではないか, と推察 される.しかしながら, 腎の微小循環は, レニンー アンギオテンシン系以外にあ種々の体液性, 神経 性因子によって調節されており，今後の検討が必 要である.

ところで, グルカゴンは尿中 $\mathrm{Na}, \mathrm{K}, \mathrm{Cl}$ などの 電解質排泄を促進する ${ }^{5)}$ が，われわれの今回のグ ルカゴン投与量では，正常人では尿中電解質排泄 は変化しなかったが，腎疾患患者では, $\mathrm{Na}, \mathrm{Cl}$ の排泄が增えた。さらに患者では，尿中 $\mathrm{Na}, \mathrm{K}$, $\mathrm{Cl}$ の排泄の変化量は GFR, ERPF の変化量と, そ れぞれ有意の正の相関をむつととが観察された.

結語：1）正常人では，グルカゴン負荷により, GFR は增加したが ERPF は不変であった，慢性 糸球体㛑炎患者では, GFR, ERPF とも增加した。 2) 尿中電解質排泄は, 慢性系球体简炎患者で, GFR, ERPF の変化と, 正の相関した変化が観察 された.

\section{文 献}

1) Ueda, J., Nakanashi, H., Miyazaki, M. et al.: Effects of glucagon on the renal hemodynamics of dogs. Eur. J. Pharmacol., 41 : 209-212 (1977).

2) Parving, H. H., Noer, I., Kehlet, H. et al. : Effect of short-term glucagon infusion on kidney function in normal man. Diabetologia, $13: 323-$ 325 (1977).

3) Parving, H.-H., Sandahl-Christiansen, J., Noer, I. et al.: The effect of glucagon infusion on kidney function in short-term insulin-dependent juvenile diabetics. Diabetologia, 19:350-354 (1980).

4) Fernandez-Cruz, A., Jr., North, R. H., Heldler, R. G. et al.: Glucagon stimulation of plasma renin activity in humans. J. Clin. Endocrinol. Metab., 41 : 183-185 (1975).

5) Elrick, H., Hoffmann, E. R., Hlad, C. L. et al. : Effects of glucagon on renal function in man. J. Clin. Endocrinol. Metab., 18 : 813-824 (1958). 